\title{
Meat Yield of Lambs of Serbian "Improved Pirot Sheeps" Depending on Slaughter Results
}

\author{
Jasmina Stojiljkovic ${ }^{1, ~ *}$, Zoran Stojiljkovic ${ }^{2}$ \\ ${ }^{1}$ Department of Food Technology, College of Applied Studies, Academy of Vocational Studies, Vranje, Republic of Serbia \\ ${ }^{2}$ Meat Science, Faculty of Agricultural Sciences and Food, University “St Cyril and Methodius”, Skopje, Macedonia
}

Email address:

jasmina_vranje@yahoo.com (J. Stojiljkovic), zoran140366@gmail.com (Z. Stojiljkovic)

*Corresponding author

To cite this article:

Jasmina Stojiljkovic, Zoran Stojiljkovic. Meat Yield of Lambs of Serbian “Improved Pirot Sheeps” Depending on Slaughter Results. International Journal of Applied Agricultural Sciences. Vol. 4, No. 4, 2019, pp. 91-95. doi: 10.11648/j.ajpb.20190404.16

Received: July 22, 2018; Accepted: August 2, 2018; Published: October 30, 2019

\begin{abstract}
Lambs of "improved Pirot sheep", divided into three groups (6 male and 6 female in each group). The first group of lambs was fattened for 60 days, the second 120 and the third 180 days. At the end of the fattening, the lamb is slaughtered by the usual technique. Objective of this research was measurement of body mass prior to slaughtering, slaughter weight and to determine the meat yield (dressing percentage) depending on the length of the fattening and gender of the lamb. With increasing of fattening weights and fattening time, the yield of meat decreases, because the weight of the offal increases. Between all three groups for male and female lambs in a body mass before slaughtering, in a mass of a warm carcass with head and offal, in a body mass of a cold carcass with head and offal, in a body mass of a cold carcass without a head and offal there is a significant difference on the level $(\mathrm{P}<0,001)$. In a dressing percentage of a warm carcass with head and offal, a dressing percentage of a cold carcass with head and offal, as well as a dressing percentage of a cold carcass without head and offal, for male and female lambs, there are a significant difference between the first and the second and the first and the third group levels $(\mathrm{P}<0.001)$. The results of examination the slaughtering characteristics show that female lambs of the first group achieved significant $(\mathrm{P}<0.05)$ higher yield of meat, compared to male lambs. Differences in other examined properties are not statistically significant. In the second group, the male lambs achieved higher body mass before slauthering and slaughter mass of female lambs $(\mathrm{P}<0.05)$, but no significant differences were found in the yield of meat. In the third group, male lambs achieved higher body mass before slauthering and slaughter mass, but female achieved higher yield of meat $(\mathrm{P}<0.05)$.
\end{abstract}

Keywords: Pre-Slaughter Body Weight, Slaughter Weight, Dressing Percentage, Lamb, Meat

\section{Introduction}

The global growing tendency of lamb and mutton meat production has been evidenced, [1]. For sustainable sheep and goat production, it is necessary to know a number of biological, technological, organizational and market factors, [2]. The new Strategy for Agriculture and Rural Development in Serbia from 2014 to 2024 defines goals and priorities for further development of agriculture, [1]. Grasslands in Serbia represent natural resource and great production potential in development and improvement of livestock production, especially in hilly-mountainous regions which have not been exploited to the full extent so far [3-5].

The historical data concerning the characteristics of the
Pirot sheep are scarce. The environmental conditions and poor pastures were the main factors that influenced the formation of Pirot sheep, [6]. According to [7], the body mass of an adult sheep was about $41 \mathrm{~kg}$. Ewes of Pirot Zackel are polled. The lack of detailed description of the breed reflected the widespread policy that autochthonous animal breeds were "primitive", low in productivity and the signature of poverty. The selection of "improved animals" through crossbreeding with imported animals high in productivity was implemented as a compulsory measure of animal breeding and sheep reproduction practice in Socialist Yugoslavia. Even so, the Pirot sheep was highly appreciated for its good milk and wool quality. The length of lactation was around 190 days, and the average milk yield per lactation was $77.5 \mathrm{~kg}$ [7]. The wool yield was very low -1.4 
$\mathrm{kg}$ per ewe, and $1.8 \mathrm{~kg}$ per ram [7]. The mandatory crossbreedings with Merino Precos and Wurtenbergin aiming to select larger animals for meat, increase the production of finer wool and preserve the milk production started in 1954, and the so-called "improved Pirot sheep" type was developed.

Research of [8], was carried out in population of R2 generation Pirot pramenka $\mathrm{x}$ Pirot improved sheep during period of three years. Lambs were divided into three groups: the first from $2.5 \mathrm{~kg}$ to $3.5 \mathrm{~kg}$; the second from $3.6 \mathrm{~kg}$ to 4.5 $\mathrm{kg}$; the third from $4.6 \mathrm{~kg}$ to $5.5 \mathrm{~kg}$. Weight of lambs was controlled at birth, with 30,60 and 90 days of age. Average body weight at birth of the tested lambs was $3.35 \mathrm{~kg}$ in the first group, $4.30 \mathrm{~kg}$ in the second group and $5.06 \mathrm{~kg}$ in the third group. At 30 days of age, the body weight of the lambs was $10.19 \mathrm{~kg}$ in the first group, $11.39 \mathrm{~kg}$ in the second and $12.49 \mathrm{~kg}$ in the third group. All these differences in body weight of lambs at birth were statistically highly significant $(\mathrm{P}<0.01)$. With 60 days of age, average body weight was $16.48 \mathrm{~kg}$ in the first group, $19.01 \mathrm{~kg}$ in the second and 20.49 $\mathrm{kg}$ in the third group. Differences between groups of lambs at this age were statistically very significant $(\mathrm{P}<0.01)$. On the end of experiment at 90 days of lambs age, we have found the following values of the body weight of lambs: $26.35 \mathrm{~kg}$ in the first group, when the second $30.49 \mathrm{~kg}$ and $28.93 \mathrm{~kg}$ in the third group. Differences between groups of lambs at this age were statistically very significant $(\mathrm{P}<0.01)$.

\section{Materials and Methods}

\subsection{Animals and Experimental Design}

The experiment included a total of 36 lambs from the purified ennobled sheep divided into 3 groups ( 6 males and 6 females), according to the duration of the fattening period, as follows: I group 60 days fattening; II group 120 days fattening and III group 180 days fattening, at the farm Djumruk on Vlasina Lake, Republic of Serbia, at an altitude of over $1250 \mathrm{~m}$ in the environment that is environmentally clean. The test is performed only in lambs, lambing as unions, an intense form of lamb growing.

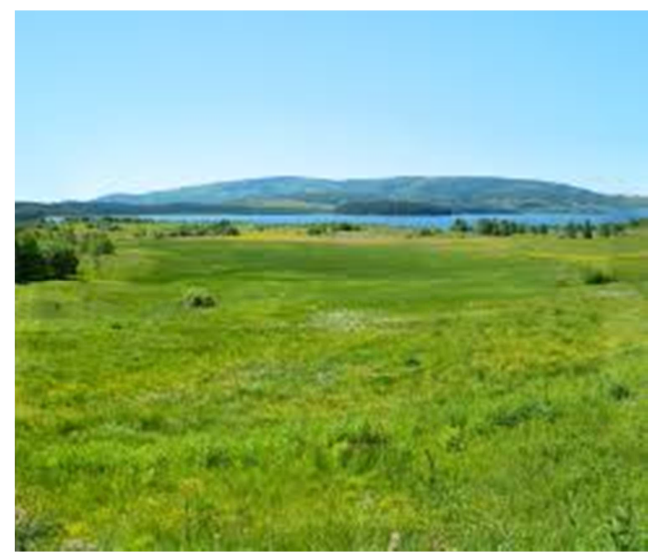

Figure 1. A typical pasture on the Vlasina Lake, Republic of Serbia.

\subsection{Plane of Nutrition}

The daily meal of sheep breastfeeding from the beginning of the experiment to the $40^{\text {th }}$ day consisted of: seeds $1.8 \mathrm{~kg} /$ lamb; silage $1.5 \mathrm{~kg}$ / lamb and concentrate $0.5 \mathrm{~kg} /$ lamb.

In the first 10 days, the mother's milk was present in the diet of the lambs, and from the $11^{\text {th }}$ day until the end of the fattening, all three groups of lambs had at their disposal a pelleted concentrate and a quality seeds at will, whose consumption was monitored and recorded every day. The lambing period of the lambs was completed on the $40^{\text {th }}$ day of their life.

In the diet of all three groups of lambs, the pelleted concentrate and the quality seeds were represented until the end of the experiment and that no group was pasture or used any other foods.

\subsection{Transport and Health Inspection of Lambs}

After finishing the fattening, the lambs were slaughtered in the slaughterhouse Jugokop - Bujanovac, Serbia, which had an export character, which means that all necessary prerequisites for processing and storage of the meat received were met, according to the strict European standards.

Each group of lambs from farm to slaughterhouse was transported by truck. Twelve hours before slaughter, food was broken at the lambs, while water was available until loading in a truck.

Immediately after the landing of the lambs in the livestock depot, a visual inspection was carried out by the veterinary inspection, which concluded that all the lambs were in good condition, with good health and that they could go to slaughter.

\subsection{Slaughter Procedure, Carcass Characteristics and Dissections}

The slaughter of the lambs is carried out according to the technological procedure, according to the following phases: preparing lamb for slaughter; raising to the track; bleeding; removing the skin; evisceration and cooling.

After taking the linear measures is done cutting left half on basic parts, and their measurement. Then, the calculated values of the yield of individual tissues (meat, fat, bones) in the main parts of the carcass. After slaughtering the lambs, the primary processing and cooling, the halves are cut into the main parts.

\subsection{Statistical Analysis}

Variational statistical analysis was performed by analyzing the variance of two-factorial experiment $(3 \times 2)$, according to [9]. The differences in the mean values were tested with the Tukey test.

\section{Results and Discussion}

Average body weight immediately before slaughter of male lambs of the first group was $18.42 \mathrm{~kg}$ (Table 1). The 
dressing percentage of warm carcass with head and offal was $55.94 \%$. The dressing percentage of cold carcass with head and offal was $54.22 \%$ and the dressing percentage of cold carcass without head and offal was $45.22 \%$. Average body weight immediately before slaughter of female lambs of the first group was $16.92 \mathrm{~kg}$ (Table 2). The dressing percentage of warm carcass with head and offal was $57.65 \%$. The dressing percentage of cold carcass with head and offal was $56.25 \%$ and the dressing percentage of cold carcass without head and offal was $47.74 \%$.

Average body weight immediately before slaughter of male lambs of the second group was $30.75 \mathrm{~kg}$ (Table 1). The dressing percentage of warm carcass with head and offal was $54.17 \%$. The dressing percentage of cold carcass with head and offal was $52.03 \%$ and the dressing percentage of cold carcass without head and offal was $43.61 \%$. Average body weight immediately before slaughter of female lambs of the second group was $26.25 \mathrm{~kg}$ (Table 2). The dressing percentage of warm carcass with head and offal was $54.62 \%$. The dressing percentage of cold carcass with head and offal was $53.33 \%$ and the dressing percentage of cold carcass without head and offal was $42.66 \%$.

Average body weight immediately before slaughter of male lambs of the third group was $37.08 \mathrm{~kg}$ (Table 1). The dressing percentage of warm carcass with head and offal was $52.99 \%$. The dressing percentage of cold carcass with head and offal was $52.01 \%$ and the dressing percentage of cold carcass without head and offal was $42.09 \%$. Average body weight immediately before slaughter of female lambs of the third group was $33.50 \mathrm{~kg}$ (Table 2). The dressing percentage of warm carcass with head and offal was $54.95 \%$. The dressing percentage of cold carcass with head and offal was $53.88 \%$ and the dressing percentage of cold carcass without head and offal was $43.32 \%$.

Table 1. Body mass prior to slaughtering, slaughter weight and dressing percentage for male lambs.

\begin{tabular}{|c|c|c|c|c|c|c|c|c|c|}
\hline \multirow{3}{*}{ Testing properties } & \multicolumn{9}{|l|}{ Group } \\
\hline & \multicolumn{3}{|l|}{$\mathbf{I}$} & \multicolumn{3}{|l|}{ II } & \multicolumn{3}{|l|}{ III } \\
\hline & $\mathbf{x}$ & SD & $\mathbf{C v}$ & $\mathbf{X}$ & SD & $\mathbf{C v}$ & $\mathbf{x}$ & SD & $\mathrm{Cv}$ \\
\hline Pre-slaughter body weight (kg) & $18.42^{\mathrm{a}}$ & 3.51 & 19.08 & $30.75^{\mathrm{b}}$ & 2.82 & 9.18 & $37.08^{\mathrm{c}}$ & 0.46 & 1.23 \\
\hline Weight of warm carcass with head and offal $(\mathrm{kg})$ & $10.28^{\mathrm{a}}$ & 1.82 & 17.71 & $16.65^{\mathrm{b}}$ & 1.45 & 8.72 & $19.65^{\mathrm{c}}$ & 1.37 & 6.98 \\
\hline Weight of cold carcass with head and offal $(\mathrm{kg})$ & $9.98^{\mathrm{a}}$ & 1.83 & 18.29 & $16.28^{\mathrm{b}}$ & 1.44 & 8.87 & $19.28^{\mathrm{c}}$ & 1.36 & 7.03 \\
\hline Loss at cooling $(\%)$ & $3.06^{\mathrm{a}}$ & 1.17 & 38.13 & $2.25^{\mathrm{a}}$ & 0.19 & 8.32 & $1.86^{\mathrm{a}}$ & 0.16 & 8.45 \\
\hline Weight of cold carcass with out offal $(\mathrm{kg})$ & $8.34^{\mathrm{a}}$ & 1.64 & 19.71 & $13.41^{\mathrm{b}}$ & 1.30 & 9.72 & $15.61^{\mathrm{c}}$ & 1.05 & 6.78 \\
\hline Dressing percentage of cold carcass with head and offal $(\%)$ & $54.22^{\mathrm{a}}$ & 1.43 & 2.63 & $52.03^{\mathrm{b}}$ & 0.57 & 1.09 & $52.01^{\mathrm{b}}$ & 0.79 & 1.52 \\
\hline Dressing percentage of cold carcass with out head and offal $(\%)$ & $45.22^{\mathrm{a}}$ & 1.65 & 3.64 & $43.61^{\mathrm{b}}$ & 0.27 & 0.63 & $42.09^{\mathrm{b}}$ & 0.39 & 0.94 \\
\hline
\end{tabular}

abc - The mean values in a single row marked with different letters are significantly different $(\mathrm{P}<0.001)$; SD - Standard deviation; Cv - Coefficient of variation

Results of research [10], indicate that medium heavy kids (average body mass prior to slaughtering $17.61 \mathrm{~kg}$ ) realize the best meat yield, i.e. higher dressing percentage of cooled carcass $(55.85 \%)$ compared to light (average body mass prior to slaughtering $12.65 \mathrm{~kg}$ ) whose dressing percentage was slightly $(\mathrm{P}>0.05)$ lower $54.69 \%$, and heavier kids (average body mass prior to slaughtering $22.70 \mathrm{~kg}$ ) whose dressing percentage was considerably $(\mathrm{P}<0.05)$ lower $52.93 \%$.

Table 2. Body mass prior to slaughtering, slaughter weight and dressing percentage for female lambs.

\begin{tabular}{|c|c|c|c|c|c|c|c|c|c|}
\hline \multirow{3}{*}{ Testing properties } & \multicolumn{9}{|l|}{ Group } \\
\hline & \multicolumn{3}{|l|}{$\mathbf{I}$} & \multicolumn{3}{|l|}{ II } & \multicolumn{3}{|l|}{ III } \\
\hline & $\mathbf{X}$ & SD & $\mathbf{C v}$ & $\mathbf{X}$ & SD & $\mathbf{C v}$ & $\mathbf{X}$ & SD & $\mathbf{C v}$ \\
\hline Pre-slaughter body weight (kg) & $16.92^{\mathrm{a}}$ & 1.96 & 11.58 & $26.25^{\mathrm{b}}$ & 1.08 & 4.13 & $33.50^{\mathrm{c}}$ & 3.27 & 9.76 \\
\hline Weight of warm carcass with head and offal $(\mathrm{kg})$ & $9.73^{\mathrm{a}}$ & 0.98 & 11.09 & $14.34^{\mathrm{b}}$ & 0.59 & 4.14 & $18.40^{\mathrm{c}}$ & 1.75 & 9.48 \\
\hline Weight of cold carcass with head and offal $(\mathrm{kg})$ & $9.48^{\mathrm{a}}$ & 0.79 & 8.33 & $14.00^{\mathrm{b}}$ & 0.60 & 4.25 & $18.05^{\mathrm{c}}$ & 1.73 & 9.58 \\
\hline Loss at cooling $(\%)$ & $2.44^{\mathrm{a}}$ & 1.84 & 75.32 & $2.36^{\mathrm{a}}$ & 0.17 & 7.12 & $1.95^{\mathrm{a}}$ & 0.19 & 9.74 \\
\hline Weight of cold carcass with out offal $(\mathrm{kg})$ & $8.05^{\mathrm{a}}$ & 0.71 & 8.84 & $11.20^{\mathrm{b}}$ & 0.65 & 5.84 & $14.51^{\mathrm{c}}$ & 1.44 & 9.91 \\
\hline Dressing percentage of warm carcass with head and offal (\%) & $57.65^{\mathrm{a}}$ & 2.44 & 4.23 & $54.62^{\mathrm{b}}$ & 0.85 & 1.55 & $54.95^{\mathrm{b}}$ & 1.18 & 2.15 \\
\hline Dressing percentage of cold carcass with head and offal (\%) & $56.25^{\mathrm{a}}$ & 2.51 & 5.27 & $53.33^{\mathrm{b}}$ & 1.41 & 2.64 & $53.88^{\mathrm{b}}$ & 1.07 & 2.03 \\
\hline Dressing percentage of cold carcass with out head and offal $(\%)$ & $47.74^{\mathrm{a}}$ & 2.51 & 5.27 & $42.66^{\mathrm{b}}$ & 1.41 & 3.30 & $43.32^{\mathrm{b}}$ & 1.07 & 2.48 \\
\hline
\end{tabular}

abc - The mean values in a single row marked with different letters are significantly different $(\mathrm{P}<0.001)$; SD - Standard deviation; Cv - Coefficient of variation

Between all three groups of male and female lambs in a body mass before slaughtering, in a mass of a warm carcass with head and offal, in a body mass of a cold carcass with head and offal, in a body mass of a cold carcass without a head and offal there is a significant difference on the level $(\mathrm{P}<0.001)$.
In a dressing percentage of a warm carcass with head and offal, a dressing percentage of a cold carcass with head and offal, as well as a dressing percentage of a cold carcass without head and offal, for male and female lambs, there are a significant difference between the first and the second and the first and the third group levels $(\mathrm{P}<0.001)$. 
Table 3. Compare slaughter results by gender of the lambs.

\begin{tabular}{|c|c|c|c|c|}
\hline Testing properties & Group & Male & Female & Difference \\
\hline \multirow{3}{*}{ Pre-slaughter body weight $(\mathrm{kg})$} & I & 18.42 & 16.92 & $1.50^{\mathrm{ns}}$ \\
\hline & II & 30.75 & 26.25 & $4.50^{*}$ \\
\hline & III & 37.08 & 33.50 & $3.58^{*}$ \\
\hline \multirow[t]{2}{*}{ Weight of warm carcass with head and offal $(\mathrm{kg})$} & II & 16.65 & 14.34 & $2.31^{*}$ \\
\hline & III & 19.65 & 18.40 & $1.25^{\star}$ \\
\hline \multirow{2}{*}{ Weight of cold carcass with head and offal $(\mathrm{kg})$} & I & 9.98 & 9.48 & $0.50^{\mathrm{ns}}$ \\
\hline & III & 19.28 & 18.05 & $1.23^{*}$ \\
\hline \multirow{3}{*}{ Loss at cooling $(\%)$} & I & 3.06 & 2.44 & $0.62^{\text {ns }}$ \\
\hline & II & 2.25 & 2.36 & $0.11^{\mathrm{ns}}$ \\
\hline & III & 1.86 & 1.95 & $0.09^{\text {ns }}$ \\
\hline \multirow{3}{*}{ Weight of cold carcass with out offal (kg) } & I & 8.34 & 8.05 & $0.29^{\text {ns }}$ \\
\hline & II & 13.41 & 11.20 & $2.21^{*}$ \\
\hline & III & 15.61 & 14.51 & $1.10^{*}$ \\
\hline \multirow{2}{*}{ Dressing percentage of warm carcass with head and offal (\%) } & I & 55.94 & 57.65 & $1.71^{*}$ \\
\hline & III & 52.99 & 54.95 & $1.96^{*}$ \\
\hline \multirow{3}{*}{ Dressing percentage of cold carcass with head and offal (\%) } & I & 54.22 & 56.25 & $2.03^{*}$ \\
\hline & II & 52.03 & 53.33 & $0.45^{\mathrm{ns}}$ \\
\hline & III & 52.01 & 53.88 & $1.87^{\star}$ \\
\hline \multirow{3}{*}{ Dressing percentage of cold carcass with out head and offal $(\%)$} & I & 45.22 & 47.74 & $2.52^{*}$ \\
\hline & II & 43.61 & 42.66 & $0.95^{\mathrm{ns}}$ \\
\hline & III & 42.09 & 43.32 & $1.23^{*}$ \\
\hline
\end{tabular}

* $-\mathrm{P}<0.05 ;$ ns -not significant

Table 3 provides a comparison of the slaughtering results according to the gender of the lambs. The results of the examination of the slaughtering characteristics show that female lambs of the first group achieved significant $(\mathrm{P}<0.05)$ higher yield of meat, compared to male lambs. Differences in other examined properties are not statistically significant.

In the second group, the male lambs achieved higher body mass before slauthering and slaughter mass of female lambs $(\mathrm{P}<0.05)$, but no significant differences were found in the yield of meat.

In the third group, male lambs achieved higher body mass before slauthering and slaughter mass, but female achieved higher yield of meat $(\mathrm{P}<0.05)$. The results from Table 1 and 2 show that with increasing of fattening weights and fattening time, the yield of meat decreases because the weight of the offal increases. It was established that heavier kids have lower dressing percentage $(55.01 \%)$ compared to lighter $(57.21 \%)$ and medium heavy kids (58.21\%), [10].

Supporting the current study, various authors [11-14] reported higher fatness level in lambs fed concentrate in sheepfold than lambs fed on pasture and concomitant dressing percentage increase. Group of authors [15] also reported an increase in fatness level of carcass with increasing slaughter weight of lambs. In study of [16] there are differences between rearing groups in terms of slaughter weight of lambs which were slaughtered at the same age - (winter rearing) lambs had the highest slaughter weight compared with other groups (springsummer rearing and autumn rearing).

\section{Conclusion}

With increasing of fattening weights and fattening time, the yield of meat decreases, because the weight of the offal increases. Between all three groups of male and female lambs all slaughtering properties there was a significant difference on the level $(\mathrm{P}<0.001)$. In a dressing percentage of a warm carcass with head and offal, a dressing percentage of a cold carcass with head and offal, as well as a dressing percentage of a cold carcass without head and offal, for male and female lambs, there are a significant difference between the first and the second and the first and the third group levels $(\mathrm{P}<0.001)$. The results of the examination of the slaughtering characteristics show that female lambs of the first group achieved significant $(\mathrm{P}<0.05)$ higher yield of meat, compared to male lambs. Differences in other examined properties are not statistically significant. In the second group, the male lambs achieved higher body mass before slauthering and slaughter mass of female lambs $(\mathrm{P}<0.05)$, but no significant differences were found in the yield of meat. In the third group, male lambs achieved higher body mass before slauthering and slaughter mass, but female achieved higher yield of meat $(\mathrm{P}<0.05)$.

\section{References}

[1] Savić, M., Beckei, Z., Dimitrijević, B., Vučković, S., Prodanović, Sand Vegara M (2014). Organic lamb meat production in Serbia based on autochthonous zackel breed: opportunities and challenges. Proceedings of the International Symposium on Animal Science 2014, September 2014, Belgrade-Zemun.

[2] Petrovic, P. M., Petrovic, C. V., Ruzic Muslic, D., Maksimovic, N., Cekic, B., Ilic, Z. Z and Kurcubic, V (2017). Strategy for Sustainable Development and Utilization of Sheep and Goat Resources in Serbia. ICSAFS Conference Proceedings $2^{\text {nd }}$ International Conference on Sustainable Agriculture and Food Security: A Comprehensive Approach Volume 2017. 
[3] Lazarević, D., Dajić, Z., Vučković S and Terzić, D (2010). Production of livestock food on natural and sown grasslands. Biotechnology in Animal Husbandry 26: 219-234

[4] Vučković, S., Simić, A., Ćupina, B., Krstić and Duronić, G (2010). Effect of mineral fertilization on yield of Agrostidetum vulgaris - type meadows in mountainous grasslands in Serbia. Biotechnology in Animal Husbandry 26: 389-394.

[5] Simić, A., Vasiljević, S., Vučković, S., Tomić, Z., Bjelić, Z and Mandić, V (2011). Herbage yield andbotanical composition of grass-legume mixture at different time of establishment. $3^{\text {rd }}$ International congress "New Perspectives and Challenges of Sustainable Livestock Production", 5-7 October 2011, Belgrade.

[6] Stevanovic,. N. O., Stojiljkovic, M., Trailovic, R., Ivanov, S and Nedic, N. D (2016). Primary phenotypical characterization of the Pirot sheep from Stara Planina, Republic of Serbia: can we save the forgotten zackel? Animal Genetic Resources 59: 63-72.

[7] Mitic, N (1984). Sheep farming. Belgrade, Serbia, Institute for Textbooks and Teaching Aids (on Serbian).

[8] Petrović, P. M., Petrović, C. V., Ilić, Z., Ružić Muslić, D., Petrović, M. M., Stojković, J and Maksimović, N (2014). Relationship between birth weight and body growth characteristics of lambs. Biotechnology in Animal Husbandry 30 (2): 193-201.

[9] Sokal, R. R and Rohlf J. F (1995). Biometry. Freeman and Company. New York.
[10] Žujović, M., Josipović, S., Tomić, Z., Stanišić, N and Nešić, Z (2008). Meat yield of kids of Serbian white breed depending on the body mass prior to slaughtering. Biotechnology in Animal Husbandry 24 (5-6): 61-69.

[11] Díaz, M. T., Velasco, S., Caneque, V and Lauzurica, S (2002). Ruiz de Huidobro. F. Perez. C. Gonzalez. J.. and Manzanares. C.: Use of concentrate or pasture for fattening lambs and its effect on carcass and meat quality. Small Rum. Res., 43: 257268.

[12] Cañeque, V., Velasco, S., Diaz, M. T., Huidobro, F. R., Perez. Cand Lauzurica. S (2003). Use of whole barley with a protein supplementto fatten lambs under different management systems and its effecton meat and carcass quality. Anim. Res.. 52: 271-285. 2003.

[13] Karim, S. A., Porwal, K., Kumar S and Singh, V. K (2007). Carcass traitsof Kheri lambs maintained on different system of feeding management. Meat Science 76: 395-401.

[14] Ekiz, B., Yilmaz, A., Ozcan, M and Kocak, O (2012). Effect of production system on carcass measurement and meat quality of Kivircik lambs. Meat Science 90: 465-471.

[15] Peña, F., Cano, T., Domenech, V., Alcalde, M., Martos, J., García-Martinez, A., Herrera M and Rodero E (2005). Influence of sex. slaughter weight and carcass weight on "non-carcass" and carcass quality in segureñ lambs. Small Rum. Res., 60: 247-254.

[16] Yalcintan, H., Ekiz,. B., Kocak, O., Dogan, N., Akin, D. P and Yilmaz, A (2017). Carcass and meat quality characteristics of lambs reared in different seasons. Archives Animal Brreding. 60: 225-233. 